\title{
GENETIC DIFFERENTIATION BETWEEN TWO HUMAN POPULATIONS CONSIDERING ON SOME DYNAMIC AND STATIC MORPHOLOGICAL PROPERTIES
}

\section{Adisa Ahmić1 \\ Emir Halilović \\ Brankica Milić}

\author{
Original scientific paper \\ DOI:10.21554/hrr.091703
}

University of Tuzla, Faculty of Natural Sciences and Mathematics, Department of Biology, B\&H

Received: 12.05 .2017

Accepted: 24.07.2017

\begin{abstract}
In this paper, we report on the first data connected to the phenotype diversity of the Roma population from north/eastern Bosnia and its genetic relations with neighboring non-Roma populations. Genetic structure of the Roma and non-Roma population was analyzed considering on four the static-morphological and three the dynamic-morphological properties. A total of 847 samples have been collected from unrelated individuals in the area of the north/eastern Bosnia. The investigated parameters of genetic heterogeneity were estimated by: the recessive phenotypes frequency observed property, chi-squared test, exact-test, pairwise FST and genetic distance analysis. Estimation of genetic variability of the analyzed populations showed significant genetic differentiation between of the Roma and non-Roma population. The basic factors of the found significant genetic differentiation between the Roma and non-Roma population are a result of a high level of endogamy, the reproductive isolation of the Roma population and limited maternal gene flow with neighboring populations.
\end{abstract}

Key words: Roma population, genetic differentiation, phenotype systems

\section{INTRODUCTION}

Linguistic, cultural-anthropological (Fraser, 1992; Marushiakova \& Popov, 2001; Ioviţă \& Shurr, 2004) and genetic studies (Greshem et al., 2001; Mendizabal et al., 2011; Gómez-Carballa et al., 2013; Moorjani et al., 2013) show that the Roma (Gypsy) have originally come from Indian subcontinent 1.5 thousand years ago. Studies have shown that the Roma populations share a common genetic history, as evidenced by classical, mtDNA and Y-chromosomal markers (Kalaydjieva et al., 2001; Chaix et al., 2004; Morar et al., 2004; Zhivotovsky et al., 2004).

The European Roma are a founder population of common origins that has subsequently split into multiple socially divergent and geographically dispersed groups (Clarke, 1973; Morar et al., 2004; KlarićMartinović, 2009). A single founder population of the European Roma have hight level intargenetic homogenity as a consequence reproductive isolation and endogamy (Mendizabal et al., 2012; Siváková et al., 1994; Mastana \& Papiha 1992). Also, studies of the Roma populations have indicated that the genetic heterogeneity of the Roma is evident in all European countries. The basic factors significant genetic differentiation between different the Roma populations and neighboring non-Roma populations are a result of a high level of endogamy, cultural identity, the reproductive isolation and limited intergroup maternal gene flow.

\section{${ }^{1}$ Correspodence to:}

Adisa Ahmić, University of Tuzla, Faculty of Natural Sciences and Mathematics, Department of Biology Univerzitetska 4, 75000 Tuzla, B\&H

E-mail: adisa.ahmic@untz.ba 
Unlike other founder populations, whose genealogy has been extensively documented, the demographic history of the Roma is not fully understood and, given the lack of written records, has to be inferred from current genetic data. Anthropological and genetic studies the Roma populations suggest that cultural identity, endogamy and reproductive isolation have played an important role in preserving genetic isolation and homogeneity of the Roma population. In the recent studies of the genetic structure of the Bosnian human population, the Roma have not been subject of research. This is the first study on the genetic structure of the Bosnian Roma population considering observed the classical genetic markers. Our study primarily focuses on the analysis genetic heterogeneity and genetic diversification of the Roma population with neighboring non-Roma Bosnian populations.

\section{MATERIAL AND METHODS}

\section{Population samples}

A total of 847 samples have been collected from unrelated individuals in the area of the north/eastern Bosnia. The samples have been contained from two categories: the Roma population and the non-Roma population. The population genetic structure of the populations was analyzed application two phenotype systems with corresponding properties: the static-morphological properties (form of the earlap, the hairiness secondary digital phalanx, the flexion of the distal phalanx of the little finger, the digital index) and the dynamic-morphological properties (flexibility of the language, extensibility proximal joint of the thumb and extensiveness distal joint of the thumb) (Table 1). Prior to sampling, all participants provided consent for the collection of samples and subsequent analysis.

\section{Population-genetic analyses}

Estimation of genetic variability of the Roma population and its comparison with the observed of the non-Roma populations was done using inter- and intragroup genetic indices. Classic populationgenetic analyses included: estimation relative frequency of the recessive allele observed phenotype systems and analysis chi-square test using a statistical program SPSS Statistics 17.0 for Windows (SPSS Inc., Chicago, IL, USA). For the assessment of intergroup genetic differentiation pairwise FST analysis was used (Weir \& Cockerham, 1984). The genetic distance between populations was calculated according to Reynolds et al. (1983). As an additional test of interpopulation differentiation, exacttest (Raymond \& Rousset, 1995) based on fenotype frequencies was used. The population genetic structure was analysed using methods implemented in the Arlequin ver 3.0 software (Excofier et al., 2005).

Table 1 Observed phenotype systems and their genetic determinants

\begin{tabular}{|c|c|c|}
\hline Phenotype systems & Observed allele & Recessive genotype/phenotype \\
\hline form of the earlap & $L>l$ & ll / coalesced earlap \\
\hline hairiness digital phalanx finger & $D>d$ & $d d /$ no-hairiness phalanx \\
\hline flexion of the distal & $R C F>r c f$ & rcfrcf / curved phalanx \\
\hline \multicolumn{3}{|l|}{ phalanx of the little finger } \\
\hline digital index $(ð ð)$ & $L K>l d$ & lklk / longer forenfinger \\
\hline flexibility language & $R>r$ & $\mathrm{rr} /$ no-flexibility language \\
\hline extensibility proximal knuckle of the thumb & $D H T>d h t$ & $\begin{array}{c}\text { dhtdht / hyperextensibility } \\
\text { proximal knuckle }\end{array}$ \\
\hline extensibility distal knuckle of the thumb & PHT $>$ pht & $\begin{array}{c}\text { phtpht / hyperextensibility distal } \\
\text { knuckle }\end{array}$ \\
\hline
\end{tabular}




\section{RESULTS}

The frequency of the recessive phenotype and the recessive allele of the observed phenotype systems of the Roma population and comparative non-Roma population are showed in Tables (2-8). In our study, the majority of the examined individuals of the Roma origin have recessive phenotype observed the gene locus (Tables 3-7). Graphical display the frequency of the recessive allele at particular phenotypic properties between of the Roma and comparative non-Roma population is showed in Figure 1.

The analysis the chi-square test (Tables 2-8) between of the comparative populations shows significant difference $(\mathrm{p}<0.05)$ in distribution recessive phenotype between the Roma and non-Roma population for five phenotype properties (excluding two: the recessive phenotype "the flexibility language" and "the digital index").

The value of the phenotype diversity in the Roma population $(0.7957+/-0.0041)$ was lower in relation to the comparative non-Roma population $(0.8509+/-0.0031)$. For the assessment of intergroup genetic differentiation pairwise FST analysis (Weir \& Cockerham, 1984) and the exact-test (Reymondt \& Rousset, 1995) was used. Significant pairwise FST difference $(0.067, \mathrm{p}<0.05)$ was found between the Roma and non-Roma population. A population differentiation exact test pointed on significant differences in distribution recessive phenotype between the observed populations. Genetic relations of the comparative populations are presented with the values of genetic distance (0.070).

Table 2 Frequency recessive phenotype "form of the earlap", the recessive alleles $q$ and statistical significance of observed differences between comparative populations

\begin{tabular}{lcccccc}
\hline Population & $\mathbf{N}$ & $\mathbf{R f}$ & $\mathbf{R}$ & $\mathbf{q}^{\mathbf{1}}$ & $\chi^{\mathbf{2}}$ & $\boldsymbol{p}$ \\
\hline Non-Roma & 472 & 179 & 0.38 & 0.61 & \multirow{2}{*}{0.84} & 0.001 \\
Roma & 375 & 14 & 0.03 & 0.19 & & \\
\hline
\end{tabular}

$* \mathrm{p}<0.05$

Table 3 Frequency recessive phenotype "hairiness digital phalanx", the recessive alleles q and statistical significance of observed differences between comparative populations

\begin{tabular}{lcccccc}
\hline Population & N & Rf & R & $\mathbf{q}^{\text {d }}$ & $\chi^{2}$ & $p$ \\
\hline Non-Roma & 472 & 120 & 0.25 & 0.50 & 143.15 & 0.001 \\
Roma & 375 & 301 & 0.80 & 0.89 & & $p$
\end{tabular}

$* \mathrm{p}<0.05$

Table 4 Frequency recessive phenotype "flexion of the distal phalanx of the little finger", the recessive allele $q$ and statistical significance of observed differences between comparative populations

\begin{tabular}{lcccccc}
\hline Population & $\mathbf{N}$ & $\mathbf{R f}$ & $\mathbf{R}$ & $\mathbf{q}^{\mathbf{l k}}$ & $\chi^{\mathbf{2}}$ & $\boldsymbol{p}$ \\
\hline Non-Roma & 221 & 131 & 0.59 & 0.77 & 0.0 & 1.0 \\
Roma & 187 & 112 & 0.60 & 0.77 & & \\
\hline
\end{tabular}

$* \mathrm{p}<0.05$

Table 5 Frequency recessive phenotype "digital index", the recessive allele $q$ and statistical significance of observed differences between comparative populations

\begin{tabular}{lcccccc}
\hline Population & $\mathbf{N}$ & $\mathbf{R f}$ & $\mathbf{R}$ & $\mathbf{q}^{\mathbf{l k}}$ & $\chi^{2}$ & $\boldsymbol{p}$ \\
\hline Non-Roma & 221 & 131 & 0.59 & 0.77 & 0.0 & 1.0 \\
Roma & 187 & 112 & 0.60 & 0.77 & & \\
\hline
\end{tabular}

$* \mathrm{p}>0.05$ 
Table 6 Frequency recessive phenotype "flexibility language", the recessive allele $q$ and statistical significance of observed differences between comparative populations

\begin{tabular}{lcccccc}
\hline Population & $\mathbf{N}$ & $\mathbf{R f}$ & $\mathbf{R}$ & $\mathbf{q}^{\mathbf{r}}$ & $\chi^{2}$ & $\boldsymbol{p}$ \\
\hline Non-Roma & 472 & 215 & 0.46 & 0.67 & 3.66 & 0.06 \\
Roma & 375 & 201 & 0.54 & 0.73 & & \\
\hline
\end{tabular}

$* \mathrm{p}>0.05$

Table 7 Frequency recessive phenotype "extensibility proximal knuckle of the thumb", the recessive allele $q$ and statistical significance of observed differences between comparative populations

\begin{tabular}{lcccccc}
\hline Population & $\mathbf{N}$ & $\mathbf{R f}$ & $\mathbf{R}$ & $\mathbf{q}^{\text {pht }}$ & $\chi^{2}$ & $\boldsymbol{p}$ \\
\hline Non-Roma & 472 & 123 & 0.26 & 0.51 & \multirow{2}{*}{0.001} \\
Roma & 375 & 306 & 0.82 & 0.90 & & \\
\hline
\end{tabular}

$* \mathrm{p}>0.05$

Table 8 Frequency recessive phenotype "extensibility distal knuckle of the thumb", the recessive allele $q$ and statistical significance of observed differences between comparative populations

\begin{tabular}{lcccccc}
\hline Population & N & Rf & R & $\mathbf{q}^{\text {dht }}$ & $\chi^{2}$ & $p$ \\
\hline Non-Roma & 472 & 303 & 0.64 & 0.80 & 280.61 & 0.001 \\
Roma & 375 & 19 & 0.05 & 0.22 & & \\
\hline
\end{tabular}

$* \mathrm{p}>0.05$

Table 9 Frequency recessive allele observed gene locus in comparative populations

\begin{tabular}{ccccccccc}
\hline Population & N & l & d & rcf & lk & r & pht & dht \\
\hline Roma & 375 & 0.19 & 0.89 & 0.70 & 0.77 & 0.73 & 0.90 & 0.22 \\
Non-Roma & 472 & 0.61 & 0.50 & 0.63 & 0.77 & 0.67 & 0.51 & 0.80 \\
\hline
\end{tabular}

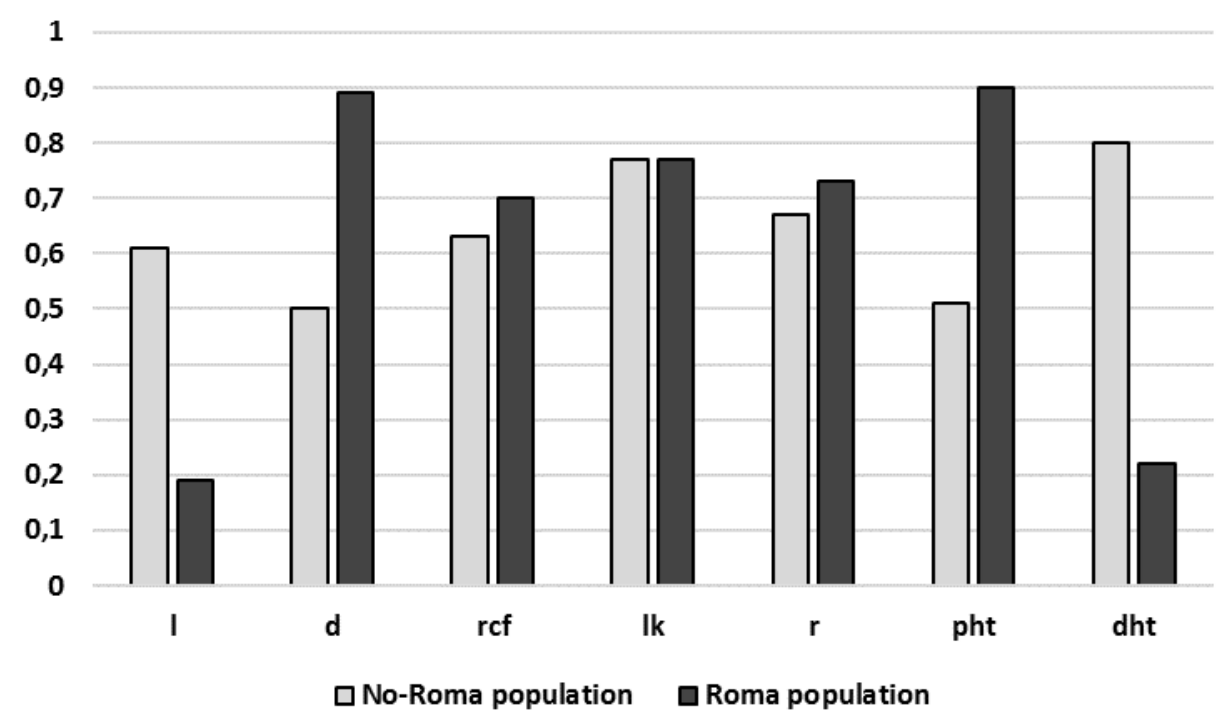

Figure 1 Distribution frequency of the recessive allele at particular phenotypic properties 


\section{DISCUSSION}

Prevoius studies based on the analysis classis genetic parameters (Siváková et al., 1994; Mastana \& Papiha 1992; Tauszik et al., 1984; Bernasovsky et al., 1994) suggest that the Roma populations show reduced intragroup genetic diversity and significant genetic differentiation with other populations. This studies indicated that genetic differentiation among the Roma populations and between Roma and non-Roma populations determined by high rate migration, isolation, genetic drift and inbreeding of the Roma population. Also, recent studies of the Roma populations based on the analysis molecular data (Greshem et al., 2001; Kalaydjieva et al., 2001; Klarić-Martinović, 2009; Mendizabal et al., 2011; Mendizabal et al., 2012; Gómez-Carballa et al., 2013) have indicated that the genetic homogeneity of the Roma groups is evident in all European countries, as a consequence reproductive isolation and endogamy and that the demographic history of the Roma is rich and complex.

Special attention in this study was paid to the analysis of genetic structure of the Roma population and its comparison with the observed of the non-Roma populations population from the area north/eastern are done using intra and intergroup genetic indices. In our study classic intra-genetic parameters indicated that the majority of the examined individuals of the Roma origin have recessive phenotype observed the gene locus. The value of the phenotype diversity in the Roma population was lower in relation to the comparative population. The majority observed phenotype properties have detected significant differences in distribution of recessive phenotype between the Roma and non-Roma population. A relatively high percentage of the recessive phenotypes and reduced phenotype diversity supports a relative higher degree the reproductive isolation and endogamy in Bosnian Roma population. Lower values of this parameter may be due to slightly higher frequencies recessive phenotypes that are noted in our study. Our study shows that the Roma population a rather genetically closed population in relation to the comparative non-Roma population. The data obtained in the study are correspondent with date previous studies based on the analysis classis genetic parameters (Siváková et al., 1994; Mastana \& Papiha 1992; Tauszik et al., 1984; Bernasovsky et al., 1994).

In this study, estimation of inter-genetic variability of the analyzed populations showed significant differentiation between the genetic structure of the Roma and non-Roma population. A population differentiation exact-test and pairwise FST analysis pointed on significant differences in gene pool between the observed populations. Also, the study by Tauszik et al., (1984) based on the analysis classis genetic parameters indicate on the interpopulational genetic differentiation of the analysed population Hungarian Roma and non-Roma population. We suggest that the ba- sic factors of the found significant genetic differentiation between Roma and the comparative non-Roma population from the area north/eastern are a result of a high level of endogamy, small size population, reproductive isolation of the Roma population, strong drift effect and limited intergroup gene flow with neighboring populations.

\section{CONCLUSION}

The data obtained in the study are correspondent with the historical documentation of the Roma, which suggests that the cultural identity, endogamy and reproductive isolation have played an important role in preserving genetic isolation and homogeneity of the Roma population. Consequently, we suggest that important determination and incorporate date about the Roma population in recent Bosnian, regional and European base of the date. Further studies with more dedicated geographical sampling and molecular data would help in defining of gene profile of the Bosnia Roma population, as well as further details of their subsequent history.

Disclosure of interest: The authors report no conflicts of interest.

This study was approved by the Council of Department of Biology Faculty of Natural Sciences, University of Tuzla, Bosnia and Herzegovina. Our study follows the principles of the Declaration of Helsinki and all subjects gave their consent to participate in this study.

\section{REFERENCES}

Bernasovský, I, Halko, N., Biros, I., Siváková, D. \& Jurícková, J. (1994). Some genetic markers in Valachian (Olachian) Gypsies in Slovakia. Gene Geography, 8 (2), 99107.

Clarke, V.A. (1973). Genetic factors in some British Gypsies, in Genetic Variation in Britain (D.F. Roberts and E. Sunderland, eds.), pp. 181-196, London: Taylor and Francis.

Chaix, R., Austerlitz, F., Morar, B., Kalaydjieva, L. \& Heyer, E. (2004). Vlax Roma history: what do coalescent-based methods tell us? European Journal of Human Genetics, 12(4), 285-292.

Excoffier, L., Laval, G., \& Schneider, S. (2005). Arlequin (version 3.0): An integrated software package for population genetics data analysis. Evolutionary Bioinformatics Online, 1, 47-50.

Fraser, A. (1992). The peoples of Europe: The Gypsies. (2nd ed.), Oxford: Blackwell Publishers. ISBN 978-0-63119605-1.

Gómez-Carballa, A., Pardo-Seco, J., Fachal, L., Vega, A., Cebey, M., Martinón-Torres, N., Martinón-Torres, F. \& Salas, A. (2013). Indian Signatures in the Westernmost Edge of the European Romani Diaspora: New Insight from Mitogenomes. PLoS One, 8(10), e75397. 
Gresham, D., Morar, B., Underhill, P.A., Passarino, G., Lin, A.A., Wise, Ch., Angelicheva, D., Calafell, F., Oefner, P.J., Shen, P., Tournev, I., de Pablo, R., Kuĉinskas, V., Perez-Lezaun, A., Marushiakova, E., Popov, V. \& Kalaydjieva, L. (2001). Origins and Divergence of the Roma (Gypsies). American Journal of Human Genetics, 69(6), 1314-1331.

Ioviţă, R. \& Schurr, T.G. (2004). Reconstructing the origins and migrations of diasporic populations: the case of the European gypsies. American Anthropologist, 106, 267-281.

Klarić-Martinović, I. (2009). Y kromosom i potraga za novom domovinom. Tragom kromosoma $Y$ od južnoazijskih do balkanskih pustopoljina: genetička prošlost i zbilja Roma i Bajaša. Zagreb: Sveučilišna knjižara.

Kalaydjieva, L., Calafell, F., Jobling, M.A., Angelicheva, D., de Knijff, P., Rosser, Z.H., Hurles, M.E., Underhill, P., Tournev, I., Marushiakova, E. \& Popov, V. (2001). Patterns of inter- and intra-group genetic diversity in the Vlax Roma as revealed by Y chromosome and mitochondrial DNA lineages. European Journal of Human Genetics, 9(2), 97-104.

Mastana, S.S., \& Papiha, S.S. (1992). Origin of Romany Gypsies - Genetic Evidence,. Journal of Morphology and Anthropometry (Germany), 79:43-51.

Marushiakova, E. \& Popov, V. (2001). Gypises in the Ottoman Empire: a contribution to the history of the Balkans. (D. Kenricki, ed.), Paris: Centre de recherches tsiganes; Hatfield: University of Hertfordshire Press.

Mendizabal, I., Valente, C., Gusmão, A., Alves, C., Gomes, V., Goios, A., Parson, W., Calafell, F., Alvarez, L., Amorim, A., Gusmão, L., Comas, D. \& Prata, M.J. (2011). Reconstructing the Indian origin and dispersal of the European Roma: a maternal genetic perspective. PLoS One, 6(1), e15988.

Mendizabal, I., Lao, O., Urko, M.M., Wollstein, A., Gusmão, L., Ferak, V., Ioana, P., Jordanova, A., Kaneva, R., Kouvatsi, A., Kučinskas, V., Makukh, H., Metspalu, A., Rosario de Pablo, N., Pamjav, H., Radojkovic, D., Rolleston, S., Sertic, J., Comas, D. \& Kayser, M. (2012). Reconstructing the Population History of European Romani from Genome-wide Data. Current Biology, 22(24), 2342-2349.
Moorjani, P., Patterson, N., Loh, P-R., Lipson, M., Kisfali, P., Melegh, B.I., Bonin, M., Kádaši, L., Rieß, O., Berger, B., Reich, D. \& Melegh, B. (2013). Reconstructing Roma History from Genome-Wide Data. PLoS One, 8(3), e58633.

Morar, B., Gresham, D., Angelicheva, D., Tournev, I., Gooding, R., Guergueltcheva, V., Schmidt, C., Abicht, A., Lochmuller, H., Tordai, A., Kalmar, L., Nagy, M., Karcagi, V., Jeanpierre, M., Herczegfalvi, A., Beeson, D., Venkataraman, V., Carter, K.W., Reeve, J., De Pablo, R., Kucinskas, V. \& Kalaydjieva, L. (2004). Mutation History of the Roma/Gypsies. American Journal of Human Genetics, 75(4), 596-609.

Raymond, M. \& Rousset, F. (1995). An Exact Test for Population Differentiation. Evolution, 49(6), 1280-1283.

Reynolds, J., Weir, B.S. \& Cockerham C.C. (1983). Estimation of the coancestry coefficient: Basis for a short term genetic distance. Genetics, 105, 767-779.

Siváková, D., Sieglová, Z., Lubyová, B. \& Nováková, J. (1994). A genetic profile of a Romany (Gypsy) subethnic group from a single region in Slovakia. Gene geography, 8(2), 109-116.

Tauszik, T., Friss, A., Gyódi, E., Santora, Z., Takács, S, Kotvász, A, Tóth, A,M, Horváth, M, Tarján, L. \& Petrányi, G. (1985). Genetic polymorphism of the Gypsy population in Hungary as based on studies of red blood cell antigens. Haematologia (Budap)., 18(3), 205-17.

Zhivotovsky, L.A., Underhill, P., Cinnioğlu, C., Kayser, M., Morar, B., Kivisild, T., Scozzari, R., Cruciani, F., Destro-Bisol, G., Spedini, G., Chambers, G.K., Herrera, R.J., Yong, K.K., Gresham, D., Tournev, I., Feldman, M.W. \& Kalaydjieva, L. (2004). The effective mutation rate at $\mathrm{Y}$ chromosome short tandem repeats, with application to human population-divergence time. American Journal of Human Genetics, 74(1), 50-61.

Weir, B.S. \& Cockerham, C.C. (1984). Estimating F-Statistics for the Analysis of Population Structure. Evolution, 38:(6), 1358-137. 